\title{
Analyzing The Presentation Of Geometry Material Based On Bruner's Theory In Mathematics Textbook
}

\author{
Dimas Abdi Haidar ${ }^{1}$, Fajar Surya Hutama², Sunardi ${ }^{3}$ \\ 1, 2,3 University of Jember, Jalan Kalimantan No.37, Sumbersari, Jember, Indonesia \\ ${ }^{1}$ Correspondence Adress; dimashaidar147@gmail.com
}

\begin{abstract}
This research aims to know the conformity of presentation based on Bruner's theory on fourthgrade mathematics textbook. This is qualitative research. The object of research is the material presentation of a fourth-grade mathematics textbook. Based on the analysis of theorem of presentation by Bruner, the facets chapter obtains a percentage of $56 \%$ which belongs to the appropriate category. The circumference and width chapter obtains a percentage of $92 \%$ which belongs to the appropriate category. The line connection chapter obtains a percentage of $50 \%$ which belongs to the appropriate category. The angle measuring chapter obtains a percentage of $56 \%$ which belongs to the appropriate category. The overall percentage of the geometry textbook is $64 \%$ which belongs to the appropriate category. The percentage of enactive aspects implemented in the presentation of geometry in mathematics textbook is $28 \%$., the percentage of iconic aspects implemented in the presentation of geometry in mathematics textbook is $73 \%$, and the percentage of the symbolic aspect is $56 \%$.
\end{abstract}

Keywords: Geometry; Mathematics Textbook; Bruner's Theory.

\section{INTRODUCTION}

Learning resource is a very important component for the improvement of educational quality. One of the learning resources that are very commonly used in school is a textbook. According to Muslich (2010:50), textbook are books that are used by students at certain levels as a medium of learning (instructional) related to a particular field of study. The Ministry of Education and Culture Regulation Number 8 of 2016 article 1 paragraph 1 explains that a textbook lesson is the main learning resources to achieve Basic Competence (KD) and Core Competence (KI) and has been declared feasible by the Ministry of Education and Culture for use in the education unit. The use of textbook as a learning resource is very important in the learning process. For teachers, textbook can help in the process of delivering materials, while for textbook students are very useful in the activity of independent learning and help support the understanding of the material presented by the teacher.

The Ministry of Education and Culture Regulation Number 24 of 2016 states that the implementation of learning in Elementary School is carried out by an integrated thematic learning approach, except for the subjects of mathematics and physical education sport and health (PJOK) as stand-alone subjects for grades IV, V, and VI. The Ministry of Education and Culture has assessed mathematics textbook that are suitable to be used as learning resources to support the implementation of learning in Elementary School. The results of this assessment are contained in the Ministry of Education and Culture's decree Number 147 of 2016 concerning the determination of mathematics and PJOK textbook for Grade IV of Elementary School. Textbook, especially in mathematical material, should contain content that is in accordance with the stages of cognitive development so that students can learn textbook better. 
Geometry as one of the material in mathematics requires skills in the learning process. Kusni (2008:6) states that the geometry is a mathematical structure that discusses elements and relationships that exist among the elements of points, lines, areas, and spaces which are abstract objects as the basic elements of geometry. Geometry is one of the systems in mathematics that preceded by a base concept, i.e. the point is then used to form lines and compile a field (Prihandoko, 2006:174). Based on some of these opinions, it can be seen that geometry is a branch of mathematics that studies the relationships on the element of points, lines, areas, and spaces. Geometry learning is very important to be taught in elementary school because it is considered very close to the environment of students. Geometry in the fourth grade of Indonesian elementary school contains material about Polygon, Perimeter, and Area of Plane, Relationship between Lines, Measurement of Angles.

Safrina (2014:10) argues that geometry is a part of mathematics that is very close to students because almost all visual objects that exist around students are geometric objects. Geometry learning in addition to paying attention to understanding the concepts presented also needs to prioritize the level of students thinking. Based on the results of previous studies, it is known that some mathematics textbook published by the government still have some geometric concepts that are less precise and presentation materials that are not in accordance with student cognitive development (Yurniwati, 2015; Irawati, 2014; and Melissa, 2015). Objects of elementary school geometry studies that are close to the environment around students should be presented according to students' cognitive thinking stages. Soedjadi (2004) states that the presentation of the content of mathematics lessons in textbook needs to be adjusted to the thinking ability of students in elementary school who are between the "preoperational" to "concrete operational" stages. Skemp (1971:36) states that the presentation of mathematical material is arranged hierarchically and is carried out in stages starting from concrete objects to abstract concepts, and simple objects to complex concepts. Bruner (1960) states that the presentation of mathematical material in teaching materials and class is presented in accordance with the development of students' thinking stages and arranged hierarchically by considering the process of acquiring mathematical concepts. Therefore, the presentation of material in the 2013 curriculum of mathematics textbook must pay attention to the development of skills and the level of thinking in the process of acquiring mathematical concepts, so that they can be a source of quality learning.

One way to find out the quality of the presentation of textbook material is by analyzing the book. The analysis performed on the 2013 curriculum of mathematics textbook uses Bruner's learning theory as its parent. Bruner's theory prioritizes human cognitive development, how the learning process of human or the process of gaining knowledge, storing knowledge and transform knowledge. Bruner's theory views at rationale that humans as processors, thinkers, and creators of information so that learning activities are an active process that allows humans to find new things beyond the information given to them (Aisha, 2007:1.5). Bruner's theory views that learning outcomes can be optimal when implemented with meaningful learning that involves students actively constructing knowledge. 
There are three model stages of cognitive development according to Bruner, namely the stage of enactive, iconic, and symbolic. Bruner (in Aisha, 2007:1.6-1.7) states that the learning process will be more optimal for students if through three model stages, namely; (1) the enactive stage, learning at the enactive stage is carried out directly where students involved in manipulating (tinkering with) objects. At this learning stage, the student learns knowledge actively, using concrete objects or using real situations. The presentation of learning at the enactive stage does not involve the imagination of students or abstract words. Students will understand something from doing or do something; (2) the iconic stage, the presentation of learning at the iconic stage is carried out on internal thoughts of students presented in the form of pictures or graphics without manipulating objects directly. The knowledge learned by interpreted (manifested) in the form of visual imagery, picture, or diagram, which describe concrete activities or concrete situations. In this stage of learning language becomes one of the important things as the media of students' thinking; (3) the symbolic stage, in this stage, students are no longer using concrete objects and images. Students have been able to imagine a concept abstractly and can use the notation without dependency on the real object. Learning at this stage is presented in the form of abstract symbols, namely the symbol used based on the agreement of people in the concerned areas, both verbal symbols (such as letters, words, sentences, mathematical symbols) and others.

In addition to proposing the theory of learning based on children's cognitive development, Bruner (in Aisha, 2007:1.9-1.11) also propose theorems relating to the presentation of mathematics learning. The theorems are construction theorem, notation theorem, contrast and variation theorem, and connectivity theorem. The construction theorem explains that the best way for a student to learn something or principle in mathematics is to construct or make arrangements as a representation (realization) of the concept or principle. The notation theorem explains that representation of a mathematical material will be more easily understood by students if the notation is used in accordance with the cognitive development of students. The notation is given in stages and sequences from the most simple to the most difficult.

The contrast and variation theorem explains that a mathematical concept will be more easily understood by students if the concept is contrasted or compared to other concepts so that the differences and relationships (if any) between one concept to other concepts become clear. The connectivity theorem explains that every concept, every principle, and every skill in mathematics is related to other concepts, principles, and skills. By understanding the relationship between one part to other parts of mathematics, an understanding of students to the structure and content of mathematics becomes more complete. Based on this description, the developmental theory of Bruner's thinking is considered suitable and can be used for the preparation of mathematical learning materials in the 2013 curriculum that requires students to develop thinking skills and abilities in accordance with the stages of cognitive development in the learning process.

Based on the description it can be concluded that textbook, especially in mathematical material, should contain content that is in accordance with the stages of cognitive development so that students can learn textbook better. This study aims to determine the suitability of the 
presentation of geometry material in grade IV elementary mathematics textbook based on Bruner's learning theory. Analysis of the presentation of geometry material in grade IV elementary mathematics textbook based on Bruner's theory will be carried out by compiling a data collection instrument that is "an instrument of conformity analysis of the presentation of geometry material based on Bruner's theory" and validating the instrument. This instrument contains detailed indicators which are divided into two parts, namely the indicator part of the analysis of the presentation of the material according to the cognitive development stage of Bruner's theory, and the analysis of the theorems of the presentation of mathematics material learning. After the data collection instruments are valid, data collection is done. The final stage is drawing conclusions based on data that has been obtained from data collection instruments.

\section{THE RESEARCH METHODS}

This study is descriptive quantitative research. According to Sugiyono (2009: 147), descriptive research is research used to describe a condition of data that has been collected as it is. Sukmadinata (2005) states that descriptive research does not conduct treatments or changes to the independent variables, but describes the conditions as they are. This study aims to describe and describe in detail the presentation of geometry material in mathematics textbook that are reviewed based on Bruner's theory. This study employed three methods of data collection, i.e. documentation, questionnaire, and checklist. The results of the data obtained from the checklist about the presentation of geometry material were then analyzed using descriptive statistics, specifically the mean and percentages. Borg \& Gall (2003: 290) state that to describe the sample as a whole, quantitative descriptive research can use one or more descriptive statistics namely mean, median, mode, and percentage.

Data obtained from the documentation method was the presentation of geometry material in the mathematic textbook for Grade IV Elementary School based on Bruner's theory of learning. The questionnaire method used in the instrument validation process of the suitability analysis sheet on the presentation of geometry material in a mathematic textbook based on Bruner's theory that will be given to the validator. In the checklist table, the observer first lists the indicators that will be observed on the subject of research (Herdiyansah, 2009:136). The checklist sheet in this study was designed and used to collect data in the form of the results of the suitability analysis on the geometry material in the mathematic textbook using the instrument in the suitability analysis on the presentation of geometry material in mathematic textbook based on Bruner's theory which has been validated.

This study analyzed the suitability on the presentation of geometry material in the mathematic textbook of the 2013 Curriculum for Grade IV Elementary School based on Bruner's theory. Descriptions in this study were carried out by conducting the suitability analysis on the presentation of geometric material in mathematics textbook thoroughly based on Bruner's theory of learning. Bruner's theory of learning which included three stages of cognitive development in Bruner's theory of learning (enactive, iconic, and symbolic) and four theorems of mathematical learning presentation (construction, notation, contrast and variation, and connectivity). Three stages of cognitive development in Bruner's theory were used to 
classify the presentation of geometry material in a mathematics textbook. While four theorems of mathematical learning presentation according to Bruner were used in analyzing the suitability on the presentation of geometry material in the mathematic textbook for Grade IV Elementary School.

Data resources on this study were the mathematic textbook of 2013 Curriculum for Grade IV Elementary School entitled "Matematika Untuk SD/MI Kelas IV", written by Gunanto, published by PT. Gelora Aksara Pratama, and ISBN 9786022986997. The object of the study was the material and sub-material of geometry contained in a mathematic textbook. The method used in this study was the method of documentation, questionnaire, and observation sheet. Data obtained from the documentation method is the presentation of geometry material in a mathematic textbook for Grade IV Elementary School. The questionnaire method used in the instrument validation process of the suitability analysis sheet on the presentation of geometry material in mathematics textbook. Observation sheets used in the form of the suitability analysis on the presentation of geometry material in mathematic textbook based on Bruner's theory. The suitability analysis sheet on the presentation of geometry material was divided into 2 parts. The first part was an indicator related to the three stages of cognitive development in Bruner's theory that was used to classify what stage of cognitive development is contained in the presentation of geometry material. The second part was an indicator for learning of mathematic theorems according to Bruner to determine the suitability on the presentation of geometry material in mathematics textbook.

The instrument of the suitability analysis on the presentation of geometry material about three stages of cognitive development according to Bruner's theory contained indicators that described the application of enactive, iconic, and symbolic stages. Indicators in the enactive stage included the use of the concrete objects as materials, learning resources and examples of exercises, learning activities containing the exploration of concrete objects. Indicators in the iconic stage included the inclusion of pictures or visual objects in materials, learning resources, and examples of exercises, learning activities containing the exploration of visual objects, and the use of contextual visual objects. Indicators in the symbolic stage included the use of symbols (verbal, mathematical, and other abstract symbols) in the presentation of the material, learning resources and examples of exercises, learning activities containing the exploration and the use of symbols, the symbols corresponding to the agreement in the field of mathematics.

The instrument of the suitability analysis on the presentation of geometry material to four theorems of mathematical learning according to Bruner contained indicators that described the application of construction, notation, contrast and variation, and connectivity. Indicators in the construction theorem included the inclusion of learning objectives, learning activity description, the sequence of the learning process from concrete concepts to abstract concepts. Indicators in the notation theorem included the inclusion of notation or symbols, readability, and accuracy of notation used, and the inclusion of notation information used. Indicators in the contrast and variation theorem included the inclusion of examples and not the right example in the presentation of learning, learning activities, exercises, and using a variety of examples. Indicators of the connectivity theorem included the order on presentation of the material in 
accordance with the associated concepts of knowledge and the inclusion of feedback on related materials.

The results of the percentage analysis on the presentation of geometry material based on four theorems of mathematical learning according to Bruner then performed in the table of categories as the percentage results based on Table 1 . The category classification was from the suitability percentage results on the presentation of geometry material that was modified by Arikunto (2003:57) described in Table 1 below.

Table 1. Category of Material Suitability Percentage

\begin{tabular}{cc}
\hline Suitability Percentage Results & Suitability Categories \\
\hline $80 \%<\mathrm{p} \leq 100 \%$ & Very Good \\
\hline $60 \%<\mathrm{p} \leq 80 \%$ & Good \\
\hline $40 \%<\mathrm{p} \leq 60 \%$ & Moderate \\
\hline $20 \%<\mathrm{p} \leq 40 \%$ & Deficient \\
\hline $0 \% \leq \mathrm{P} \leq 20 \%$ & Very Deficient \\
\hline
\end{tabular}

\section{THE RESULTS OF THE RESEARCH AND THE DISCUSSION}

The material that becomes the study of analysis in this study is geometry material. Geometry is one branch of mathematics that studies the relationship that exists on the element of points, lines, areas, and spaces (Safrina, 2014; Kusni, 2008; and Prihandoko, 2006). Based on the analysis that has been done, it is obtained that the application of the cognitive development stage of Bruner's theory in the geometry material in the textbook as a whole for the enactive stage is categorized as low, the iconic stage is categorized as high, the symbolic stage is categorized as moderate. The results obtained as the percentage of every sub-chapter from states of cognitive development analysis of Bruner are accumulated with other subchapters in one chapter. The result of the accumulated learning stage is presented in Table 2.

Table 2. Percentage of Cognitive Development Stage of Geometry Material

\begin{tabular}{|c|c|c|c|}
\hline No & Chapter & Stage of Cognitive Development & Percentage \\
\hline \multirow{3}{*}{1.} & \multirow{3}{*}{ Polygon } & Enactive & $64 \%$ \\
\hline & & Iconic & $57 \%$ \\
\hline & & Symbolic & $36 \%$ \\
\hline \multirow{3}{*}{2.} & \multirow{3}{*}{$\begin{array}{l}\text { Perimeter and } \\
\text { Area of Plane }\end{array}$} & Enactive & $28 \%$ \\
\hline & & Iconic & $89 \%$ \\
\hline & & Symbolic & $75 \%$ \\
\hline \multirow{3}{*}{3.} & \multirow{3}{*}{$\begin{array}{l}\text { Relationship } \\
\text { between Lines }\end{array}$} & Enactive & $19 \%$ \\
\hline & & Iconic & $66 \%$ \\
\hline & & Symbolic & $57 \%$ \\
\hline \multirow{3}{*}{4.} & \multirow{3}{*}{$\begin{array}{l}\text { Measurement } \\
\text { of Angles }\end{array}$} & Enactive & $0 \%$ \\
\hline & & Iconic & $78 \%$ \\
\hline & & Symbolic & $57 \%$ \\
\hline
\end{tabular}

In Table 2, it can be seen that in the chapter of Polygon, the most applied stage is the enactive stage, which is equal to $64 \%$. The enactive stage in the chapter of Polygon is mostly 
applied in the form of activities involving real objects around students, the explanation of the Polygon component through observations of concrete objects around students, and practice exercises involving real objects in the school environment. While the least applied stage is the symbolic stage, which is $36 \%$.

In the chapter of the Perimeter and Area of Plane, the most applied stage is the iconic stage, which is equal to $89 \%$. The application of the iconic stage in this chapter is seen in visual object-based observation activities in the book, the explanation of components in the plane figure formula using illustrated images, and various practice exercises related to visual objects. While the least applied stage is the enactive stage, which is $28 \%$. In the chapter of Perimeter and Area of Plane, most learning activities, study materials, and practice questions no longer involve real objects.

In the chapter of the Relationship between Lines, the most applied stage is the iconic stage, which is equal to $66 \%$. The iconic stage in this chapter is mostly applied in the form of visual images in the pre-activities, observational activities, explanations of the concept of relationships between lines in daily life, and visualized object-based practice exercises. While the least applied stage is the active stage, which is equal to $19 \%$. The enactive phase in the chapter of the Relationship between Lines is only applied to the pre- activities to observe real objects in the learning environment.

In the Measurement of Angles chapter, the most applied is the iconic stage, which is equal to $78 \%$. The application of the iconic stage in the Measurement of Angles chapter is contained in the pre-activity in the form of observing illustrated images of objects that have angles, visual images of objects that have different types of angles, and practice exercises with visual objects to help solve problems. In the Measurement of Angles chapter, the application of the enactive stage is not included in the presentation of the material.

The total percentage for the enactive stages applied to the presentation of geometry material in the mathematic textbook is $28 \%$, the total percentage for the iconic stage is $73 \%$, and the total percentage for the symbolic stage is $56 \%$. From the percentage of the analysis results on the application of the cognitive development stage that has been obtained, it can be seen that mathematic textbook for Grade IV Elementary School which studied have a tendency at the iconic stage on the presentation of geometry material.

The application of the enactive stage in the mathematic textbook in this study can be seen by the use of concrete objects in the environment around students which are included in introductory activities, learning media, learning activities of students, and some exercises reserved. The enactive stage in the presentation of geometry material is applied with various percentages based on Table 2, except for the chapter Measurement of Angle which does not apply the enactive stage in the presentation of the material. Sample images of the implementation of the enactive stage in the geometry material contained in Figure 1. 


Kegiatan Pengantar
Siapkan beberapa lembar koran. Lalu, amatilah lantai
kelasmu. Berapa lembar koran yang dapat menutupi
meja kelasmu? Berapa lembar koran kira-kira yang dapat
menutupi seluruh lantai kelasmu?

Figure 1. Example of Implementing the Enactive Stage

In Figure 1 contained a sentence " introductory activity: prepare several newspapers, then watch your class. how many sheets of paper can cover your class table? how many newspapers can cover the entire floor of your class?". introductory activities involving real objects are found in most chapters of geometry material.

The application of the iconic stage in mathematic textbook examined loaded with visual image illustrations form presented on some introductory activities, learning resources, material presentation, and some exercises. The application of the iconic stage in the presentation of geometry material in the mathematic textbook has been contained in every chapter with various percentages. Some examples of implementation of the iconic stage are included in Figure 2a and Figure 2b.

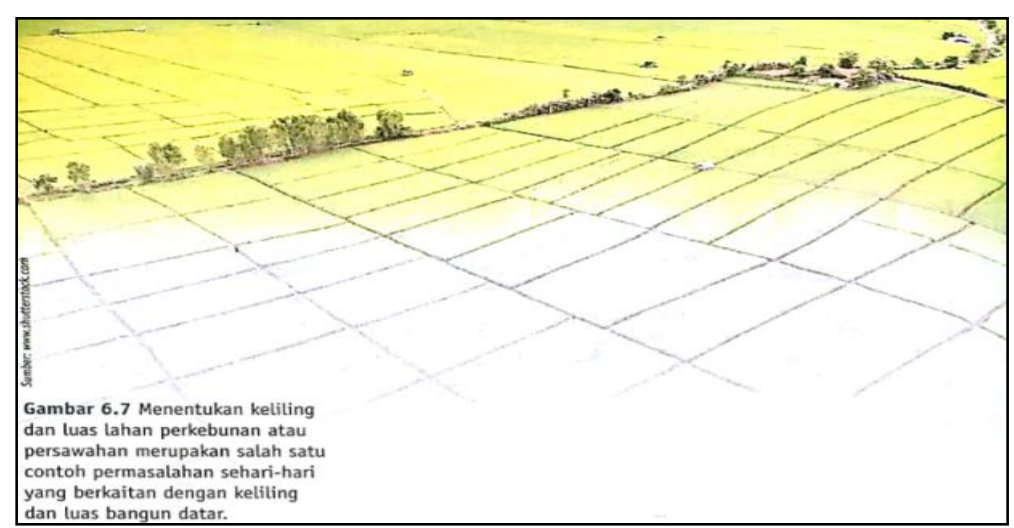

Figure 2a. Example of Implementing the Iconic Stage (Field)

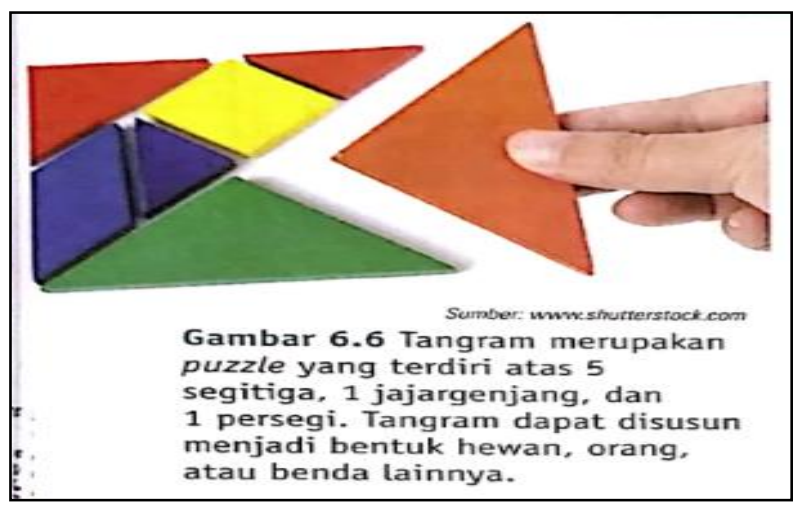

Figure 2b. Example of Implementing the Iconic Stage (Tangram) 
Figure 2a contained the sentence "determine the circumference and area of paddy fields is one example of everyday problems related to perimeter and area of a plane". Figure $2 \mathrm{~b}$ contained the sentence "Tangram is a puzzle consisting of five triangles one parallelogram and one square". The iconic stage in geometry material is generally used as a visualization of geometric objects to make it easier for students to imagine shapes.

The application of the symbolic stage in the textbook can be seen by the use of agreed symbols or notations in the field of Mathematics contained in the media and learning resources, material presentation, learning activities of students, and some exercise reserved. The symbolic stage has been applied in every chapter that presents geometry material as contained in Table 2. An example of a symbolic stage implementation is contained in Figure 3.

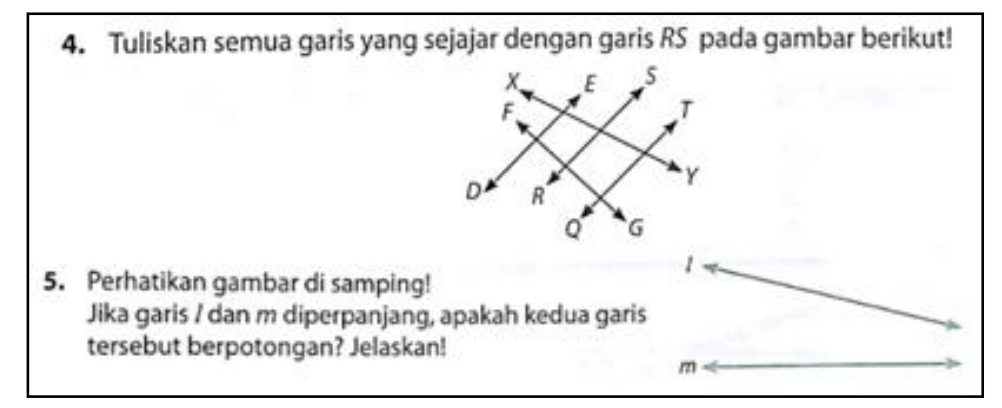

Figure 3. Example of Implementing the Symbolic Stage

In Figure 3 contained sentence "number 4. write down all lines that are parallel to the RS line in the following image; number 5. Pay attention to the following picture, if the lines $m$ and 1 are extended, do the two lines intersect? Explain!". The application of symbolic stages in geometric material is widely used in mathematical terms and mathematical formulas

Based on the results of the analysis that has been done, it can be seen that the application of the cognitive development stage of Bruner's theory depends on the material to be presented. If the material presented requires concrete objects as material delivery, the dominant learning stage applied is the enactive stage. It can be seen in the presentation of material in the Polygon chapter which applies the enactive stage of $64 \%$. If the material presented requires visual object illustration as supporting material delivery, the dominant learning stage applied is the iconic stage. It can be seen in the presentation of the dominant material applied is the iconic stage, i.e. in the Perimeter and Area of Plane which applies the iconic stage of 89\%, in the Relationship between Lines chapter which applies the iconic stage of 66\%, and in the Measurement of Angles chapter which applies the iconic stage of $78 \%$.

If the material presented require notations or symbols in the concept acquisition, then the dominant cognitive development stage used is the symbolic stage. The application of three stages (enactive, iconic, symbolic) is also influenced by the cognitive development stage of students. According to Piaget's theory about the stage of cognitive development, Grade IV students of an elementary school-aged 9-10 years old are classified as concrete operations. Piaget (in Lapono, 2009: 1.19) states that children who are included in the concrete operational stage (7-11 years old) has developed the power of logical thinking to solve concrete problems, 
the basic concepts of objects, the amount of time, space, and causality. Based on the theory of learning stage that must be used in the presentation of material in the IV grade mathematics textbook can prioritize the active activities of students in solving concrete problems.

The results of the percentage obtained by every chapter of theorem analysis in the presentation of mathematical learning according to Bruner are accumulated with other chapters in the textbook. The percentage result of theorem analysis in the presentation of mathematical learning according to Bruner presented in Graph 1 below.

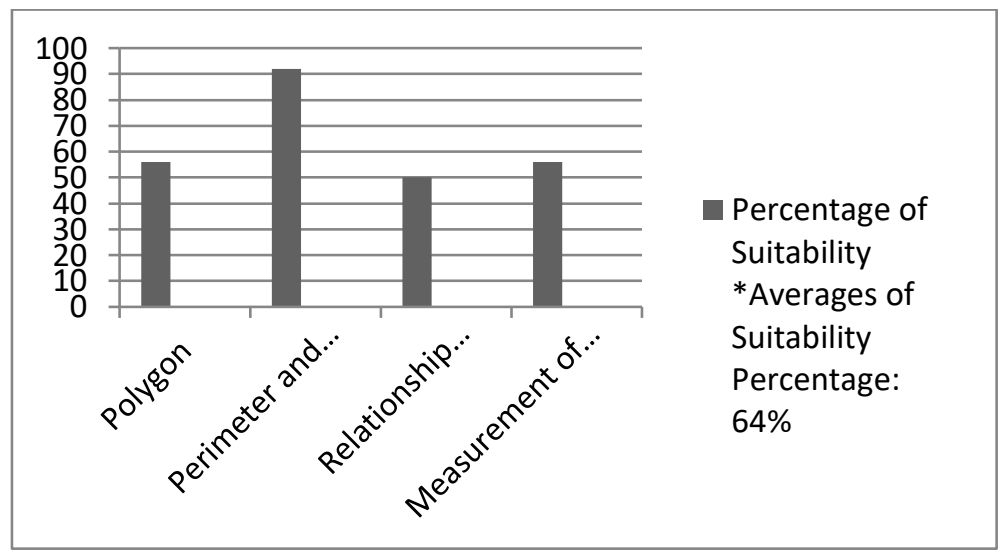

\section{Graph 1. Percentage of Suitability in Mathematical Learning Presentations}

Based on Figure 4, it can be seen that in the Polygon chapter has suitability with a percentage of $56 \%$ which means included in the moderate appropriate category. On the analysis of the construction theorem in the Polygon chapter from the total of 4 indicators, there are 3 appropriate indicators and 1 inappropriate indicator. On the analysis of the notation theorem, there are 1 appropriate indicator and 3 inappropriate indicators. The analysis conducted on the contrast and variation theorem, there are 4 appropriate indicators or it may be said that all indicators have been appropriate.

On the analysis of the connectivity theorem, there are 1 appropriate indicator and 2 inappropriate indicators. For the Perimeter and Area of Plane chapter, the suitability percentage of geometry material is $92 \%$, it showed that the category is very good or very appropriate. On analysis of the construction theorem in the Perimeter and Area of Plane from the total of 4 indicators, there are 3 appropriate indicators and 1 inappropriate indicator. On the analysis of the notation theorem from the total of 4 indicators has been appropriate and there are no inappropriate indicators. Analysis of the Polygon chapter is not carried out by using the contrast and variation theorem because the presentation of the Perimeter and Area of Plane material focuses on decreasing the Perimeter and Area of Plane formula, so procedurally this chapter does not need to apply the contrast and variation theorem. On the analysis of the connectivity theorem, there are 4 appropriate indicators and there are no inappropriate indicators.

For the Relationship between Lines chapter, the suitability percentage obtained is $50 \%$, which means included in the appropriate category. On the analysis of construction theorem in the Relationship between Lines chapter from the total of 4 indicators, there are 3 appropriate 
indicators and 1 inappropriate indicator. On the analysis of the notation theorem, there are 4 appropriate indicators and there are no inappropriate indicators. The analysis is carried out on the contrast and variation theorem contained 1 appropriate indicator and 3 inappropriate indicators. On the analysis of the connectivity theorem, there are no appropriate indicators. In the Measurement of Angles chapter, the suitability percentage on the presentation of geometry material obtained is $56 \%$ which shows that the category is moderate appropriate. On the analysis of the construction theorem in the Measurement and Angles chapter from the total of 4 indicators, there are 3 appropriate indicators and 1 inappropriate indicator. On the analysis of the notation theorem, there are 4 appropriate indicators and there are no inappropriate indicators. The analysis is carried out on the contrast and variation theorem contained 1 appropriate indicator and 3 inappropriate indicators. On the analysis of the connectivity theorem, there are 1 appropriate indicator and 3 inappropriate indicators.

The percentage for the presentation of geometry material in the mathematic textbook thoroughly is $64 \%$ which shows that the suitability on the presentation of geometry material in the mathematic textbook is included in the good or appropriate category. The results of the study conducted by Jannah (2015) and Kurnia (2013) showed that the application of Bruner's theory to geometry learning can improve student learning activities and outcomes. The mathematic textbook for Grade IV Elementary School analyzed has been in the appropriate category so that the book can be used as learning resources to support the application of geometry learning material to obtain optimal learning outcomes.

From the analysis results that have been done, it can be seen that the theorems which have the highest level of suitability thoroughly are the notation theorem, from the total of 16 question indicators are divided into 13 appropriate indicators and 3 inappropriate indicators or can be expressed with a percentage of $81 \%$, this shows that the notation used in the presentation of material on the textbook is appropriate and correct. The lowest theorems of the suitability level thoroughly are the connectivity theorem, from the total of 16 question indicators, there are 6 appropriate indicators and 10 inappropriate indicators or can be expressed with a percentage of $38 \%$, this shows that the connectivity between concepts presented is inappropriate. The incompatibility of the preparation or layout of the material presented is very influential in the process of relating concepts and knowledge that occur in students. From the analysis results, it can be seen that the ideal geometry material layout in textbook is the first chapter of the Relationship between Lines, then the Polygon chapter, the Perimeter, and Area of Plane chapter, and the last is the Measurement of Angles chapter.

The analysis results showed that the presentation of geometry material in mathematic textbook for Grade IV Elementary School has included more than one theorem in every chapter with various percentages, this is in accordance with the opinion of Aisyah (2007: 1.12) which states that the four theorem of mathematical learning which presented in Bruner's theory is not applied one by one in learning, but can be applied two or more theorems simultaneously in the process of learning certain mathematic materials. The findings in this study showed that in the mathematic textbook that have been assessed and declared feasible by the Ministry of Education and Culture, there are still inappropriate in the presentation of geometric material with the 
cognitive development stage and the theorems of presenting mathematics learning according to Bruner. These results correspond to the results of the study from Irawati (2014) and Melissa (2015), which showed that in a textbook recommendation the Government can still be found concepts that were not suitable.

\section{CONCLUSION AND SUGGESTION}

Based on the results of the analysis and discussion, it can be concluded that the suitability on the presentation of geometry material in grade IV mathematics textbook based on the theorem of mathematical learning according to Bruner, for the constructive chapter has the suitability percentage of $56 \%$ which is included in the appropriate category The Perimeter and Area of Plane chapter has the suitability percentage of $92 \%$ which is included in the very appropriate category. The Relationship between Lines has the suitability percentages of 50\% which is included in the appropriate category. The Measurement of Angles chapter has the suitability of $56 \%$ which is included in the moderate category. The percentage for the overall presentation of geometry material in the textbook is $64 \%$, thus it can be said that the suitability on the presentation of geometry material in mathematics textbook is included in the good or appropriate category.

The analysis results of Bruner's cognitive development stage stated that the Polygon chapter applied the enactive stage of $64 \%$, applied the iconic stage of 57\%, and applied the symbolic stage of $36 \%$. In the Perimeter and Area of Plane chapter applied the enactive stage of $28 \%$, applied the iconic stage of $89 \%$, and applied the symbolic stage of $75 \%$. The Relationship of Lines, chapter applied the enactive stage of $19 \%$, applied the iconic stage of $66 \%$, while the symbolic stage applied to 57\%. In the Measurement of Angles, chapter applied the enactive stage of $0 \%$, applied the iconic stage of $78 \%$, while the symbolic stage applied to $57 \%$. The application of three cognitive development stages in the material depended on the material content that was presented and the age or stage of cognitive development of students.

Based on the research result on the suitability analysis on the presentation of geometry material in mathematic textbook for fourth grade elementary school based on Bruner's learning theory, the suggestions that can be given are, the analysis results of mathematical textbook can be used as a consideration for educators to choose the book that will be used and The incompatibility of mathematical textbook based on the analysis results can be used as an improvement material for the government in assessing appropriate textbook for use in elementary schools and for publishers and writers in designing mathematical textbook.

\section{REFERENCES}

Aisyah. (2007). Pengembaangan Pembelajaran Matematika SD. Jakarta: Dirjen Dikti

Arikunto, S. (2006). Prosedur Penelitian Suatu Pendekatan Praktik. Jakarta: PT Asdi Mahasatya.

Bruner, J. S. (1960). The Proces of Education. Harvard University: Press Cambridge.

Herdiansyah, H. (2009). Metodologi Penelitian kualitatif. Jakarta: Salemba Humanika. 
Irawati, T. P., Sugiarti, T., \& Yuliati, N. (2014). Analisis Kesesuaian Materi Geometri dalam Buku Sekolah Elektronik Ayo Belajar Matematika untuk SD/MI Kelas IV Berdasarkan Kriteria Bell. Skripsi. Jember: FKIP Universitas Negeri Jember.

Jannah, A. S. (2015). Penerapan Teori Bruner pada Pembelajaran Matematika Pokok Bahasan Jaring-Jaring Kubus dan Balok untuk Meningkatkan Aktivitas dan Hasil Belajar Peserta didik Kelas IV SDN 09 Kembiritan Banyuwangi Tahun Pelajaran 2014/2015. Skripsi. Jember: FKIP Universitas Jember.

Kurnia, D. E. (2013). Penerapan Teori Bruner melalui Model Kooperatif Tipe Numbered Heads Together pada Pembelajaran Matematika Pokok Bahasan Pecahan untuk Meningkatkan Hasil Belajar Peserta Didik Kelas IIIA SDN Ajung 03 Jember. Skripsi. Jember: FKIP Universitas Jember.

Kusni. (2008). Geometri Dasar. Semarang: Universitas Negeri Semarang.

Lapono, N, dkk. (2009). Belajar dan Pembelajaran SD. Jakarta: Direktorat Jenderal Pendidikan Tinggi Departemen Pendidikan Nasional.

Masyhud, M. S. (2016). Metode Penelitian Pendidikan. Jember: LPMP.

Melissa, M. (2015). Analisis Buku Siswa Matematika Kelas VIII Semester 1 Berdasarkan Kriteria Bell, Skripsi. Jember: FKIP Universitas Jember.

Moleong, L. J. (2011). Metodologi Penelitian Kualitatif Edisi Revisi. Bandung: PT. Remaja Rosdakarya.

Muslich, M. (2010). Text Book Writing. Jakarta: Ar-Ruzz Media.

Peraturan Menteri Pendidikan dan Kebudayaan Republik Indonesia Nomor 8 Tahun 2016. Buku yang Digunakan Oleh Satuan Pendidikan. (2016). Jakarta. http://publik22.blogspot.com/2016/03/ downloadperm en dikbud-nomor-8-tahun.html.

Peraturan Menteri Pendidikan dan Kebudayaan Republik Indonesia Nomor 24 Tahun 2014. Kompetensi Inti dan Kompetensi Dasar Pelajaran pada Kurikulum 2013. (2016). Jakarta. https://drive.google.com/file/d/0B0277pAcpXcWUEtvQVNrNVNmbTg/view?ts=578f1 e8b.

Prihandoko, A. C. (2006). Pemahaman dan Penyajian Konsep Matematika Secara Benar dan Menarik. Jakarta: Departemen Pendidikan Nasional.

Safrina, K. (2014). Peningkatan Kemampuan Pemecahan Masalah Geometri melalui Pembelajaran Kooperatif Berbasis Teori Van Hiele. Jurnal Didaktik Matematika. Vol. 1. No.1.

Skemp, R. R. (1971). The Psychology of Learning Matematics. Victoria: Penguin Books Australia Ltd.

Soedjadi, R. (2004). Kiat Pendidikan Matematika di Indonesia. Jakarta: Depdiknas

Sugiyono. (2014). Memahami Penelitian Kualitatif. Bandung: CV Alfabeta. 
Yurnitawati. (2015). Analisis Buku Teks Matematika Untuk Siswa Sekolah Dasar. Jurnal Ilmiah PGSD. Vol. 6. No.1. 